taining a column of mercury, the rising and falling of which under influences of barometric pressure raised or lowered the centre of gravity of the pendulum and varied the rate of the clock accorlingly. The clock-train in both instruments was so arranged that the dial-readings could, by an exceedingly simple calculation, be interpreted in terms of mean daily thermometrical or barometricali variations. $\Lambda$ s the alteration in the lengths of the pendulums takes place second by second throughout the day, it follows that the daily error of time shown on the dial must be proportional to the mean of the variations of the thermometer or barometer during the same period.

The method of estimating, by observation of the rate of an uncompensated time-keeper, the mean amount of heat received during any given period, without the necessity of recording the actual temperature at any particular time, is not by any means new, for the chronometrical thermometer, an instrument which has for many years been emplnyed at the Royal Observatory for testing the rates of chronometers under variations of temperature, is founded upon the same principle. This instrument consists of a chronometer in which the usual compensation for temperature is reversed; that is to say, in the balance the positions of the brass and the steel are interchanged, the latter being outside, so that variations of temperature produce an exaggerated effect upon the rate of the instrument.

M. von Sterneck is probably the first to su'ggest the employment of the chronometrical method to the determination of mean variations in the vertical intensity of terrestrial magnetism, but he has, I think, been anticipated in its application to the computing of thermometric and barometric averages.

Sciestific Club, February 18

CONRAD W. COOKE

\section{BACTERIA IN WATER}

$\mathrm{I}^{\mathrm{T}}$ is weli known that water-whether tap or ordinary distilled-pussesses the property of contamiriating, with a growth of bacteria, any "cultivation" liquid" inoculated with it, but the morphological condition in which these organisms occur in it is open to question; it may be supposed on the one hand, that they exist as developed bacteria, and are not apparent under the microscope merely in consequence of their scarcity, as shown by Mr. Lister in the account of his recent admirable investigation of the lactic fermentation, to be the case with some specific ferments, or, on the other hand that they are present as "germs" of the bacteria, bodies yet far more minute than the mature forms, and on that account invisible-ultra-microscopic. Which of these alternatives is true I have endeavoured to determine by experiment, the details of which will shortly be published, and the general result is here briefly communicated.

M. Pasteur has recently stated in the Comptes Rendus that if a cylinder of water be allowed to stand for several weeks at a constant temperature, the organisms in it sink to the bottom, leaving the upper portion free, and incapable of contaminating. Following this method and placing a vessel of ordinary distilled water in an apparatus constructed for the purpose of maintaining an invariable temperature, after seven or eight days a specimen of the water was taken from the bottom of the vessel by a pipette closed with the finger and dipped into it. The water so taken was in appearance perfectly bright and pellucid, but under the microscope it was found to contain amorphous particles, some spores of filamentous fungi, micrococci in great numbers, bacteria of the common form (B. Termo) and bacilli (long and extremely slender filaments). All of these forms were motionless, or exhibited only Brownian movement. No such forms could be detected in the upper layers of the water, nor in a specimen taken from the bulk of that from which the experiments were made. As regards limpidity, there was no difference between the top and bottom portions.

I have made four experiments with specimens of water obtained from two different sources, and in all $I$ have been able by this method of subsidence to prove the presence of organisms in great numbers in the sediment. It may be mentioned that they stain with facility by
Hacmatoxylon, and are thereby rendered more readily apparent.

These observations show that bacteria occur in water under their usual forms, and that they are not generally distinguished on account of their small number, in any one portion of the water, when disseminated through its mass. The observed contaminating property of distilled water is thus accounted for without necessitating the assumption of "germs" of any sort, an hypothesis which is unsupported by observation.

The examination, by cultivation, of the difference in contaminating properties of the upper and lower layers, stated by M. Pasteur to exist, has as yet been inconclusive.

G. F. DOWDESWELL

\section{OUR ASTRONOMICAL COLUMN}

The Uranian Satellites, ARiel and Umbriel.The following positions of the two interior satellites of Uranus for the ensuing fortnight are derived from the data furnished by Mr. Marth in the January numiser of the Monthly Notices of the Royal Astronomical Society, and are for Irh. G.M.T., or about the time of the planet's meridian transit. There must be many telescopes in this country which will command the two exterior satellites, Titania and Oberon, but, so far as we know, neither Ariel nor Umbriel have yet been certainly observed here with any but Mr. Lassell's reflectors. Prof. Newcomb states that Ariel is intrinsically brighter than Umbricl; he thinks that Ariel at least belongs to that class of satellites of which the brilliancy is variable, and dependent on its position in its orbit, and he adds that the evidence of variability of some kind seems indisputable, since he has repeatedly failed to see it with the Washington refractor when the circumstances--distance from the primary not excepted-were favourable, and when the next satellite, Umbriel, though less favourably situated, was visible. "On the other hand," he remarks, "there were two occasions, I 874, January 28 , and I875, March 25, when it was surprisingly conspicuous," and at these times the angle of position was about $350^{\circ}$. Prof. Newcomb further expresses the opinion that where any difficulty is experienced in seeing the outer satellites, he would not hesitate to pronounce it impossible to see the inner ones.

Nevertheless, the success which has attended the search for one, at least, of the satellites of Mars by English observers who are provided with large instruments, may perhaps induce them to look for the close satellites of Uranus at the present opposition.
ArIEL.

\begin{tabular}{|c|c|c|c|c|c|}
\hline \multicolumn{2}{|c|}{ Feb. 22} & Pos & 179 & \multicolumn{2}{|c|}{ Dist. $13^{\prime \prime} 6$} \\
\hline , & 23 & ", & II & , & 15.1 \\
\hline & 24 & ", & 207 & ", & $11 \cdot 2$ \\
\hline " & 25 & ", & 77 & ", & $5^{2}$ \\
\hline$"$ & 26 & ", & $34^{\circ}$ & ", & $8 \% 7$ \\
\hline$"$ & 27 & ", & 181 & ", & $14^{\circ} 2$ \\
\hline & 28 & , & I3 & ", & 148 \\
\hline March & 1 & ", & 2 II & " & 102 \\
\hline " & 2 & " & 95 & $"$ & 49 \\
\hline " & 3 & " & 344 & $"$ & 98 \\
\hline " & 4 & ", & 183 & ", & $x_{4} \cdot 6$ \\
\hline ", & 5 & " & 15 & "? & 144 \\
\hline$"$ & 6 & " & 216 & 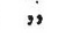 & $9^{\circ 2}$ \\
\hline$"$ & 7 & ", & II 2 & ", & $5^{\prime} \mathrm{I}$ \\
\hline
\end{tabular}

UMBRIEL.

\begin{tabular}{|c|c|c|}
\hline Po & 29 & Dist. \\
\hline ל, & 355 & " \\
\hline & 214 & $"$ \\
\hline & 178 & $"$ \\
\hline & 40 & ", \\
\hline & 웅 & ", \\
\hline & 228 & , \\
\hline & 183 & ", \\
\hline & 59 & " \\
\hline & 5 & ", \\
\hline & 253 & , \\
\hline & 187 & $"$ \\
\hline & 9 I & ", \\
\hline & 9 & ", \\
\hline
\end{tabular}

PIgOTT'S OBSERVATIONS OF VARIABLE STARS.-Some years since it was suggested, we believe, by. Prof. Argelander, that the Royal Society might have in its possession manuscripts of Edward Pigott of York, amongst which might be found observations of variable stars that would prove of importance in the history of their fluctuations. It would appear, however, that none of Pigott's papers are preserved in the Society's Archives, an ineffectual search having beẹn lately made for them. 
TIIE TEAPLE OBSERVATUKX, RUGhY.-Mr. G. M. Seabroke, as Curator of the Temple Obscrvatory, has issued a Report upon procecdings during the year 1877 . The whole of the measures of double-stars, 398 in number, during the last three years up to the time of dismantling the cld Observatory, have appeared in vol. xliii. of the Ilemoirs of the Royal Astrononical Society. Nore recently investigations into the motions of stars in the line of sight by the spectroscopic method have occupied Mr. Seabroke's attention, but the chief work in the year has been the rebuilding of the Observatory. The Report contains an outline of its history and a description of the instruments to which reference may be made in future years. The equatorial of $8 \frac{1}{1}$ inches aperture, by Alvan Clarke, was formerly in the possession of the Rev. W. R. Dawes, and an interesting letter from him upon its capabilities is appended to the Report. Not the least notable of its performances is its having shown the close satellite of Saturn, Mimas, on many occasions, and we know that its former possessor was not likely to have mistaken faint stars for the satellite.

The observatory is open to the members of the school at certain hours on fine evenings when opportunities for observing with the equatorial and transit are afforded them. It should be mentioned that in addition to the Alvan Clark refractor the observatory possesses a twelveinch With-reflector which is chiefly used with the spectroscope.

The cost of the new observatory and house for the curator, upwards of $x, 230 l$., has been defrayed by subscriptions from the masters, old Rugbeians, and others in the school, upon the occasion of its tercentenary.

\section{GEOGRAPHICAL NOTES}

AFRICAN EXPLORATION.- Ihe two African Societies of Berlin, which are now combined, have resolved to tum their attention to practical (i.e., commercial) objects as well as scientific ones with regard to the great continent in which the travels of Cameron and Stanley have revealed vast stores of the most varied products. The twin societies therefore invite all German merchants, manufacturers, \&x. , to participate in their efforts to open up a great African commerce, and announce that the German Government is ready to grant a preliminary sum of 100,000 marks $(5, \infty 00 l$.) to further the object in question. The Germans seem determined that no single nation, more especially England or Portugal, shall have the supremacy on the Congo. In Switzerland a new geographical society has been formed for the same object as the above.-An official telegram from Zanzibar to Brussels announces the death at Zanzibar of Dr. Maes and Capt. Crespel, who were sent out by the International African Association as leaders of an exploring colony in Central Africa. With them were M. Cambier and Ernest Marno, and they were to establish a station somewhere in the Tanganyika region, which would form a centre of further exploration. The death is also announced of Capt. Elton, who, with Mr. Cotterill, was surveying the route between the north end of Lake Nyassa and the east coast.

ArCtic Exploration.-The Committee on Naval Affairs of the U.S. Congress have adopted a report from $\mathrm{Mr}$. Benjamin A. Willis recommending the equipment of an Arctic expedition as proposed by Capt. Howgate. At a public meeting held by the New York Geographical Society to discuss the subject of polar exploration a paper by Capt. Howgate was read on his intended colony. Lord Dufferin, governor-general of Canada, was elected an honorary member of the Society, and returned thanks in his usual style. He referred to himself as "a potentate whose sceptre touches the pole, and who reigns over a larger area of snow than any monarch of the earth."

THE PAMIR.-We learn from the Turkestanskiya Vidomosi, that two members of the Pamir expedition, MM. Skassi and Schwarz, have returned to Tashkend,
M. Severtsoff ronaining for some time at Osh. The expedition, which started in Septemlacr last, has met with great difficulie: from dicp snow and the cold weather, the thermometer falling as low as $31^{\circ}$ Celsius below zero. Owing to the absolute want of forests, wood was brought by yalis. No inhabitants were found in the P'amir, nor even in the valley of Alay, the Kirchiz having already left the valley for varmcr rogions. The rarity of air on those great heights, which exceed I 5,000 feet, occasioned much suffering to the members of the expedition. The Valley of Alay was reached from that of Fergana, by way of the Shart Pass, and from the Alay the expedition followed the path which was followed by Gen. Skobeleff in $1876 . M$. Severtsoff reached as far as the Lok-sai River, which the natives said flows into the Lob-nor, uncler the name of the Tarim-gcl. Thence he was compelled by the deep snow to return, without reaching the problematic meridional ridge which was the aim of the expedition. Prof. Schwarz has determined the latitudes and longitudes of six places, and has made numerous magnetical observations; a complete survey of the route was made by the topographers, the heights of a hundred points were determined, partly barometrically and partly geodetically. M. Severtsoff has brought in a large ornithological collection.

EduCatronal TRAVEL.-We learn that a socicty is in course of formation at St. Petersburg for the organisation of travels for children and for young men. The travels of the children are intended for the general development of the intellectual faculties and of the power of observation, and those of the young men will be arranged so as to give them a practical knowledge of some branch of science, together with an acquaintance with their own country. The travellers will be divided into scveral groups-riatural sciences, history, etimnography, \&.c., and each section will be placed under the leadership of some well-known specialist. The success of the botanical and geological excursions, which were organised during several summers by the members of St. Petersburg and Moscow Societies of Natural Sciences, lead us to expect that the new enterprise wiil be successful.

PRShEVAlSKY Aind Maclay.-The Russian Geographical Society has received telesrans from Col. Prshevalsky, dated Fort Alexandrovsky, announcing that the traveller is now recovering from an illness, and will continue his journey to Tibet; and from Dr. Mikluho. Maclay, announcing his roturn from New Guinea to Singapore.

SEA TRADE WITI SHERLA,-We learn that several Bremen and Moscow merchants have formed a company for sea trade with Siberia. A large steamer, with two barges and a small river steamer on board, will start from Bremen in July next for the mouth of the $\mathrm{Ob}$ or of the Yenisei. Leaving the river steamer and the barges for river communication, the large steamer will return with Siberian wares.

GEOGRAPHICAL Bibliography.-In the last part for I 877 of the Zeitschrift of the Berlin Geographical Society will be found a copious list, covering 100 pages, of the principal geographical works published between November, 1876 , and November, 1877 .

Russian Geographical Society.-The Great Constantine gold medal of the Russian Royal Geographical Society was awarded this year to $M$. Zakharoff for his remarkable Manchurian dictionary, the result of many years' study of the language and life of the Manchurians, during his residence as Consul at Kuldja. The gold medal of Count Lütke was awarded to Capt. Rykacheff, of the Physical Observatory of St. Petersburg, for his researches into the distribution of atmospherical pressure throughout Russia. Small gold medals were awarded to M. Marx for ten years' meteorological observations at Yeniseisk, and to Col. Till for his levelling between the Aral and Caspian. 